\title{
PEMBELAJARAN KALKULUS DIFFERENSIAL MENGGUNAKAN MODUL DENGAN PENDEKATAN DIFFERENTIATED INSTRUCTION
}

\author{
Triana Harmini ${ }^{1}$ \\ ${ }^{1}$ Universitas Darussalam Gontor \\ 1triana@unida.gontor.ac.id
}

\begin{abstract}
Modules are one form of teaching material that can help students learn independently. For students to receive materials well, it is necessary to create a learning atmosphere by the characteristics of students. Differentiated instruction approach is a learning approach by giving different instructions according to the features of the learner. This research aims to test the effectiveness of learning methods with a differentiated instruction approach compared to differentiated instruction-based modules. This research is a pseudo-experimental study with 92 students of the Informatics Engineering study program of Darussalam Gontor University. Modules are one form of teaching material that can help students learn independently. For students to receive materials well, it is necessary to create a learning atmosphere by the characteristics of students. This research began by giving treatment in learning as many as six meetings on Derivative materials The data analysis in this study uses Oneway ANOVA. Before data analysis, the prerequisite of research is a test of normality and homogeneity. The results of the analysis prerequisites are obtained that the data is distributed normally and homogeneously. The results concluded that there were significant differences between students who were taught using differentiated instruction approaches, differentiated instruction-based modules, and direct methods.
\end{abstract}

Keywords:Calculus, differentiated instruction, learning module.

\begin{abstract}
Abstrak
Modul adalah salah satu bentuk bahan ajar yang dapat membantu mahasiswa belajar mandiri . Agar mahasiswa mampu menerima materi dengan baik perlu diciptakan suasana belajar yang sesuai dengan karakteristik mahasiswa. Pendekatan differentiated instruction merupakan pendekatan pembelajaran dengan memberikan instruksi yang berbeda sesuai dengan karakteristik peserta didik. Penelitian ini bertujuan untuk menguji efektivitas metode pembelajaran dengan pendekatan differentiated instruction dibandingkan modul berbasis differentiated instruction. Penelitian ini termasuk penelitian eksperimen semu (quasi-experiment) dengan subjek sebanyak 92 mahasiswa program studi Teknik Informatika Universitas Darussalam Gontor. Pelaksanaan penelitian ini diawali dengan memberikan perlakuan berupa pembelajaran sebanyak 6 pertemuan pada materi Turunan. Teknik analisis data yang digunakan pada penelitian ini adalah One-way ANOVA. Sebelum analisis data prasyarat analisis yang dilakukan adalah uji normalitas dan homogenitas. Hasil prasyarat analisis diperoleh bahwa data berdistribusi normal dan homogen. Hasil penelitian ini disimpulkan bahwa terdapat perbedaan yang signifikan hasil belajar mahasiswa yang diajar menggunakan pendekatan differentiated instruction, modul berbasis differentiated instruction, dan metode langsung.
\end{abstract}

Kata kunci: Kalkulus, differentiated instruction, modul pembelajaran

Cara Menulis Sitasi: Harmini, T. (2021). Pembelajaran Kalkulus Differensial Menggunakan Modul dengan Pendekatan Differentiated Instruction. Mathematic Education and Aplication Journal, volume 3 no.1, halaman 41-47.

Pada program studi Teknik Informatika, Universitas Darussalam Gontor mata kuliah Kalkulus adalah salah satu mata kuliah wajib yang harus ditempuh oleh semua mahasiswa. Salah satu capaian pembelajaran mata kuliah (CPMK) mata kuliah kalkulus adalah mahasiswa mampu menguasai konsep teroritis serta menerapkan pemikiran logis, kritis dan sistematis dalam mengaplikasikan konsep differensial (turunan) dari berbagai bentuk fungsi dalam penyelesaian masalah informatika secara 
prosedural. Berdasarkan hasil observasi awal yang telah dilakukan, CPMK matakuliah kalkulus belum dapat tercapai. Hal ini berdasarkan hasil ujian akhir semester mahasiswa pada tahun sebelumnya yaitu tahun 2019-2020 dimana sebanyak 52\% dari total seluruh mahasiswa belum memenuhi CPMK yang direncanakan. Hal ini disebabkan kurangnya bahan ajar Kalkulus yang dapat memenuhi kebutuhan mahasiswa sesuai dengan perbedaan karakteristik mahasiswa. Bahan ajar atau buku Kalkulus yang banyak beredar berisi materi dan contoh soal tanpa memperhatikan perbedaan karakteristik mahasiswa.

Bahan ajar Kalkulus yang selama ini banyak ditemukan berupa buku yang berisi kumpulan materi, contoh soal dan latihan. Menurut Mahmudah dan Fathani, bahan ajar didefinisikan sebagai seperangkat teori yang disusun secara terstruktur untuk mendukung pendidik sehingga pembelajaran menjadi lebih mudah, menyenangkan dan menarik bagi peserta didik (Mahmudah \& Fathani, 2019). Bahan ajar disusun untuk membantu mahasiswa selama proses pembelajaran. Bahan ajar menjadi media pembelajaran yang sangat penting selama proses pembelajaran karena bahan ajar dapat meningkatkan daya ingat peserta didik (Agustina \& Farida, 2019). Salah satu bentuk bahan ajar yang sering digunakan adalah modul pembelajaran.

Modul pembelajaran dirancang secara terstruktur dan sistematis agar mahasiswa mampu belajar secara mandiri sesuai dengan minat dan kemampuan mahasiswa (Wulandari et al., 2020). Modul pembelajaran sangat penting dalam proses belajar mengajar. Belajar menggunakan modul pembelajaran akan menciptakan suasana pembelajaran sehinnga peserta didik mampu menemukan cara belajar sesuai dengan minat peserta didik. Dengan mengerjakan latihan yang ada pada modul akan memberi kesempatan peserta didik mengetahui kemampuan diri (Al Azka et al., 2019). Modul disusun menggunakan kalimat yang mudah dipahami peserta didik dan dilengkapi petunjuk belajar mandiri. Dengan menggunakan modul pembelajaran, peserta didik diharapkan dapat mengembangkan semua kemampuan kemampuan dan minat yang ada pada diri setiap mahasiswa. Oleh sebab itu diperlukan modul yang mampu memberikan petunjuk atau instruksi sesuai dengan karakterisktik mahasiswa. Salah satu pendekatan pembelajaran yang mampu memberikan perbedaan isntruksi adalah differentiated instruction.

Differentiated Instruction merupakan pendekatan pembelajaran yang berbasis pada dosen dan berpusat pada mahasiswa, dimana dosen berperan penting dalam merancang pembelajaran sesuai dengan karakteristik mahasiswa (Simanjuntak \& Listiani, 2020). Dengan menggunakan pendekatan differentiated instruction mahasiswa dapat mencapai tujuan pembelajaran sesuai dengan jalur kemampuan mereka sendiri (Hidayati, 2020). Pendekatan differentiated isntruction memungkinkan semua mahasiswa untuk menggunakan kurikulum yang sama dengan memberikan skor, tugas dan hasil belajar sesuai dengan kebutuhan mereka (Ping et al., 2020). Dengan pendekatan differentiated instruction siswa dapat dibantu sesuai dengan tingkat kebutuhan mereka sendiri bukan berdasarkan kepentingan pengajar (Bajrami, 2013). Penelitian ini menggunakan pendekatan differentiated instruction sebagai pendekatan metode pembelajaran dan juga pendekatan dalam penyusunan modul 
pembelajaran mata kuliah Kalkulus 2 pada materi Diferensial (Turunan).

Dalam penelitian ini dirancang rencana pembelajaran dengan menggunakan pendekatan differentiated instruction serta modul berbasis differentiated instruction. Perbedaan instruksi pada rencana pembelajaran dan modul dirancang berdasarkan tingkat perbedaan tingkat kemampuan awal mahasiswa, yaitu rendah, sedang, dan tinggi. Capaian pembelajaran mata kuliah yang digunakan sama untuk semua tingkat kemampuan mahasiswa namun berbeda dalam tugas dan aktivitas pembelajaran. Kemampuan mahasiswa dirangsang dengan menggunakan lembar aktivitas belajar dalam diskusi kelompok berdasarkan tingkat kemampuan mereka. Pada akhir pembelajaran mahasiswa diberikan evaluasi mandiri dalam bentuk tes sesuai dengan tingkat kemampuan mahasiswa.

Berdasarkan uraian pendahuluan, penelitian ini bertujuan untuk menguji efektivitas penggunaan metode pembelajaran dengan pendekatan differentiated instruction dibandingkan modul berbasis differentiated instruction.

\section{METODE}

Penelitian ini termasuk penelitian eksperimen semu dengan menggunakan tiga kelompok yang terbagi menjadi dua kelompok eksperimen dan satu kelompok kontrol. Kelompok eksperimen pertama diajar menggunakan metode pembelajaran dengan pendekatan differentiated instruction dan kelompok eksperimen kedua diajar menggunakan modul berbasis differentiated instruction. Kelompok kontrol diajar dengan menggunakan metode ceramah dan diskusi. Pembelajaran dilakukan sebanyak 6 kali pertemuan pada materi Differensial (Turunan). Subjek penelitian ini sebanyak 92 mahasiswa program studi Teknik Informatika, Fakultas Sains dan Teknologi, Universitas Darussalam Gontor pada mata kuliah Kalkulus 2 pada tahun 2020-2021.

Pada penelitian ini, instrumen yang digunakan berupa tes. Instrumen tes berupa empat soal essay yang dilaksanakan pada pertemuan terakhir setelah materi Turunan selesai diajarkan. Untuk mengetahui kesesuaian soal dengan capaian pembelajaran yang direncanakan, sebelum digunakan tes telah divalidasi oleh dosen matematika. Pemberian tes dilakukan pada akhir pembelajaran proses pembelajaran. Siginifikansi perbedaan hasil belajar mahasiswa pada ketiga kelompok dilakukan dengan analisis data hasil belajar mahasiswa. Statistik uji yang digunakan adalah One-Way ANOVA dengan prasyarat analisis menggunakan uji normalitas dan uji homogenitas. Uji normalitas data dilakukan pada ketiga kelompok data dengan menggunakan Kolmogorov-Smirnov dan Shapiro-Wilk sedangkan untuk homogenitas data menggunakan Levene-test. Semua analisis data statistik menggunakan bantuan software IBM 
SPSS Statistic 22.

\section{HASIL DAN PEMBAHASAN}

Penelitian ini dilaksanakan pada program studi Teknik Informatika Universitas Darussalam Gontor pada tahun ajaran 2020-2021 pada mata kuliah Kalkulus2. Penelitain dilakukan pada materi TurunN (Differensial). Data yang didapatkan dalam penelitian ini berupa data hasil belajar mahasiswa. Ringkasan hasil belajar mahasiswa secara deskriptif disajikan pada Tabel 1.

Tabel 1. Ringkasan Statistika Deskriptif Hasil Belajar Mahasiswa

\begin{tabular}{|l|c|c|c|}
\hline Statistik & Kelompok eksperimen 1 & Kelompok eksperimen 2 & Kelompok kontrol \\
\hline Ukuran data & 31 & 32 & 29 \\
\hline Skor Maksimum & 92.40 & 92.80 & 81.90 \\
\hline Skor Minimum & 55.40 & 59.68 & 42.23 \\
\hline Jangkauan & 37.00 & 33.12 & 39.67 \\
\hline Rata-rata & 71.86 & 75.80 & 68.30 \\
\hline Variansi & 115.50 & 93.92 & 67.91 \\
\hline Standar Deviasi & 10.75 & 9.69 & 8.24 \\
\hline
\end{tabular}

Tabel 1 menunjukkan statistik deskriptif dari ketiga kelompok data dan diketahui dari rata-rata ketiga kelompok data terdapat perbedaan rata-rata hasil belajar mahasiswa. Rata-rata hasil belajar mahasiswa pada kelompok eksperimen 2 paling tinggi antara ketiga kelompok data sebesar 75,80 sedangkan kelompok eksperimen pertama memiliki rata-rata nilai 71,86 serta kelompok kontrol memiliki rata-rata nilai sebesar 68.30. Untuk melihat signifikansi perbedaan rata-rata hasil belajar mahasiswa pada ketiga kelompok perlu dilakukan pengujian hipotesis menggunakan uji One-way ANOVA. Prasyarat yang harus dipenuhi untuk uji One-Way ANOVA adalah uji normalitas dan homogenitas. Uji normalitas dilakukan pada ketiga kelompok data menggunakan uji Kolmogorov-Smirnov dan Shapiro-Wilk pada taraf signifikansi $\alpha=5 \%$. Ringkasan hasil uji normalitas ketiga kelompok data disajikan pada Tabel 2.

Tabel 2. Ringkasan Hasil Uji Normalitas Data

\begin{tabular}{|l|c|c|c|c|c|c|}
\hline \multirow{2}{*}{ Variabel } & \multicolumn{3}{|c|}{ Kolmogorov-Smirnov } & \multicolumn{3}{c|}{ Shapiro-Wilk } \\
\cline { 2 - 7 } & Statistic & $d f$ & Sig. & Statistic & $d f$ & Sig. \\
\hline Kelompok eksperimen 1 & .093 & 31 & .200 & .962 & 31 & .329 \\
\hline Kelompok eksperimen 2 & .108 & 32 & .200 & .956 & 32 & .212 \\
\hline Kelompok kontrol & .124 & 29 & .200 & .934 & 29 & .069 \\
\hline
\end{tabular}


Berdasarkan Tabel 2 dengan melihat nilai probabilitas (Sig.) dari uji normalitas dengan KolmogorovSmirnov pada ketiga kelompok data sama dengan $0.200>0.05$ sehingga disimpulkan bahwa ketiga kelompok data berdistribusi normal. Pada uji Shapiro-Wilk diperoleh nilai probabilitas (Sig.) kelompok eksperimen pertama sebesar $0.329>0,05$, untuk kelompok eksperimen kedua sebesar $0.212>0,05$ dan kelompok kontrol sebesar $0.069>0,05$. Sehingga disimpulkan bahwa ketiga kelompok data berdistribusi normal. Selanjutnya dilakukan uji homogenitas data dengan menggunakan Levene-test. Ringkasan hasil uji homogenitas data disajikan pada Tabel 3.

Tabel 3. Ringkasan Hasil Uji Homogenitas

\begin{tabular}{|c|r|r|l|}
\hline Levene Statistic & $d f 1$ & $d f 2$ & Sig. \\
\hline 2.239 & 2 & 89 & .113 \\
\hline
\end{tabular}

Dari Tabel 3 dengan melihat hasil nilai probabilitas (Sig.) Levene Statistic (uji F) sebesar $0.113>0.05$ sehingga disimpulkan bahwa ketiga kelompok data memiliki varians sama dan homogen. Hasil prasyarat analisis menunjukkan hasil bahwa ketiga kelompok data berdistribusi normal dan homogen sehingga ketiga kelompok data memenuhi prasyarat analisis variansi (One-way ANOVA). One-way ANOVA dilakukan untuk mengetahui signifikansi perbedaan hasil belajar mahasiswa pada ketiga kelompok data yaitu kelompok eksperimen I yang diajar menggunakan pembelajaran dengan pendekatan differentiated instruction, kelompok eksperimen II diajar menggunakan modul berbasis differentiated instruction, dan kelas kontrol diajar dengan menggunakan pembelajaran langsung yaitu metode ceramah dan diskusi. Ringkasan hasil analisis variansi One-way ANOVA dengan menggunakan IBM Statistic 22 disajikan pada Tabel 4.

Tabel 4. Ringkasan Hasil Uji One-Way ANOVA

\begin{tabular}{|l|c|c|c|c|c|}
\hline & Sum of Squares & $d f$ & Mean Square & $F$ & Sig. \\
\hline Between Groups & 857.315 & 2 & 428.657 & 4.609 & .012 \\
\hline Within Groups & 8278.023 & 89 & 93.011 & & \\
\hline Total & 9135.337 & 91 & & & \\
\hline
\end{tabular}

Dari Tabel 4 diketahui hasil penghitungan analisis variansi sebesar $F=4.609$ dengan nilai probalititas (Sig.) sebesar 0.012 kurang dari 0.05 sehingga disimpulkan bahwa terdapat perbedaan yang signifikan hasil belajar mahasiswa pada ketiga kelompok data yaitu kelompok eksperimen I yang diajar menggunakan pembelajaran dengan pendekatan differentiated instruction, kelompok eksperimen II diajar menggunakan modul berbasis differentiated instruction, dan kelas kontrol diajar menggunakan metode langsung yaitu metode ceramah dan diskusi. Selanjutnya untuk melihat perbedaan ketiga kelompok data dilakukan uji lanjut ANOVA dengan menggunakan Metode Scheffe. Ringkasan hasil uji lanjut disajikan pada Tabel 5. 
Tabel 5. Hasil Uji Komparasi dengan Scheffe

\begin{tabular}{|l|c|c|c|}
\hline \multicolumn{1}{|c|}{ Komparasi } & Mean Difference & Std. Error & Sig. \\
\hline Kelompok eksperimen 1 - Kelompok eksperimen 2 & -3.94 & 2.43 & 0.274 \\
\hline Kelompok eksperimen 1 - Kelompok kontrol & -3.55 & 2.49 & 0.366 \\
\hline Kelompok eksperimen 2 - Kelompok kontrol & 7.49 & 2.47 & 0.013 \\
\hline
\end{tabular}

Pada Tabel 5 diketahui bahwa hasil uji lanjut menggunakan metode Scheffe diperoleh nilai Sig untuk komparasi kelompok eksperimen 1 dengan kelompok eksperimen 2 sebesar 0.274 lebih besar 0.05 . Hal ini berarti tidak terdapat perbedaan yang signifikan antara hasil belajar mahasiswa yang diajar menggunakan pendekatan differentiated instruction dan mahasiswa yang diajar menggunakan modul berbasis differentiated instruction. Nilai Sig. untuk komparasi kelompok eksperimen 1 dengan kelompok kontrol sebesar 0.366 lebih besar 0.05. Hal ini menunjukkan bahwa hasil belajar mahasiswa yang diajar menggunakan pendekatan differentiated instruction dan mahasiswa yang diajar menggunakan metode langsung yaitu metode ceramah dan diskusi memberikan hasil yang sama. Hasil tersebut sejalan dengan penelitian Cannon yang menyatakan bahwa hasil belajar siswa yang diajar menggunakan pendekatan differentiated instruction dengan pembelajaran konvensional memberikan hasil yang sama (Cannon, 2017). Namun dari hasil analisis formatif, differentiated instruction mampu memenuhi kebutuhan keberagaman karakteristik siswa sehingga dapat digunakan sebagai alternatif pendekatan pembelajaran.

Nilai probalilitas (Sig.) untuk komparasi kelompok eksperimen kedua dengan kelompok kontrol sebesar 0.013 kurang dari 0.05 . Hasil ini menunjukkan bahwa terdapat perbedaan yang signifikan antara hasil belajar mahasiswa yang diajar dengan modul berbasis differentiated instruction dan mahasiswa yang diajar dengan pembelajaran langsung yaitu metode ceramah dan diskusi. Berdasarkan rata-rata hasil belajar mahasiswa yang diajar menggunakan modul berbasis differentiated instruction sebesar 75.80 sedangkan rata-rata hasil belajar mahasiswa yang diajar dengan menggunakan pembelajaran langsung yaitu metode ceramah dan diskusi sebesar 68.30. Hal ini berarti hasil belajar mahasiswa yang diajar menggunakan modul berbasis differentiated instruction lebih baik daripada hasil belajar mahasiswa yang diajar dengan menggunakan pembelajaran langsung yaitu metode ceramah. Hasil ini sejalan dengan beberapa hasil penelitian yang menyatakan bahwa mahasiswa yang diajar menggunakan modul berbasis differentiated instruction mempunyai hasil belajar yang lebih baik daripada mahasiswa yang diajar menggunakan metode langsung (Fatmianeri et al., 2021; Rokhayah, 2019).

\section{KESIMPULAN}

Dari hasil dan pembahasan dapat diambil kesimpulan dalam penelitian ini bahwa: 1) hasil belajar mahasiswa yang diajar dengan pendekatan differentiated instruction dengan mahasiswa yang diajar menggunakan modul berbasis differentiated instruction tidak menunjukkan perbedaan yang signifikan, 
2) hasil belajar pada mahasiswa yang diajar menggunakan pendekatan differentiated instruction dengan mahasiswa yang diajar menggunakan metode pembelajaran langsung juga tidak menunjukkan perbedaan yang signifikan, 3) hasil belajar mahasiswa yang diajar menggunakan modul berbasis differentiated instruction lebih baik daripada hasil belajar mahasiswa yang diajar menggunakan pembelajaran langsung.

\section{DAFTAR PUSTAKA}

Agustina, R., \& Farida, N. (2019). Analisis Kebutuhan Pengembangan Bahan Ajar Matematika Bagi Siswa Low Vision. Jurnal Pendidikan Matematika Raflesia, 04(02), 58-66.

Al Azka, H. H., Setyawati, R. D., \& Albab, I. U. (2019). Pengembangan Modul Pembelajaran. Imajiner: Jurnal Matematika Dan Pendidikan Matematika, 1(5), 224-236.

Bajrami, I. (2013). The Importance of Differentiation in Supporting Diverse Learners. 4(22), 149-155.

Cannon, M. A. (2017). Differentiated Mathematics instruction: An action research study [University of South Carolina].

Fatmianeri, Y., Hidayanto, E., \& Susanto, H. (2021). Pengembangan Modul Elektronik Berbasis Differentiated Instruction untuk Pembelajaran Blended Learning. 10(1), 50-62.

Hidayati, F. H. (2020). Differentiated instruction in the mathematics classroom: Teachers' teaching experience in a teacher professional development. International Journal on Teaching and Learning Mathematics, 3(1), 37-45.

Mahmudah, K. S., \& Fathani, A. H. (2019). Pengembangan Bahan Ajar Matematika dengan Pendekatan Pendidikan Matematika Realistik Indonesia pada Materi Sistem Persamaan Linier Dua Variabel. Jurnal Komunikasi Pendidikan, 3(1).

Ping, L. S., Salwani, I., Abdullah, R., Yasin, M., Sooria, Z., \& Bee, L. B. (2020). Jurnal Inovasi Pendidikan Matematika The Effectiveness Of Lesson Study On Differentiated Instruction Among Mathematics Head Panels In District Of Port Dickson Di fferentiated instruction ( DI) is an urgent need in education for this century (Subhan , 20. 1, 205-218.

Rokhayah, L. (2019). Desain Modul Pembelajaran Matematika Dengan Instruksi Dan Soal Sesuai Variasi Individu Siswa Pada Materi Sistem Persamaan Linear. Symmetry: Pasundan Journal of Research in Mathematics Learning and Education, 4, 1-15.

Simanjuntak, S. S., \& Listiani, T. (2020). Penerapan Differentiated Instruction dalam Meningkatkan Pemahaman Konsep Matematika Siswa Kelas 2 SD. Scholaria: Jurnal Pendidikan Dan Kebudayaan, 10(2), 134-141.

Wulandari, S., Febrini, D., \& Syafri, F. S. (2020). Pengembangan Modul Matematika yang Terintegrasi Nilai-Nilai Islam Berbasis Pendekatan Saintifik pada Materi Himpunan. Jurnal Equation: Teori Dan Penelitian Pendidikan Matematika, 3(2). 